\title{
The Effects of Secondary School Administrators' Servant Leadership Behaviors on Teachers' Organizational Commitment*
}

\author{
Fatma Türkmen ${ }^{1}$, İbrahim Gül ${ }^{2}$ \\ ${ }^{1}$ Ministry of Education, Turkey \\ ${ }^{2}$ Ondokuz Mayıs University, Turkey \\ Correspondence: İbrahim Gül, Ondokuz Mayıs University, Turkey.
}

Received: October 18, 2017

Accepted: November 11, 2017

Online Published: November 21, 2017

doi:10.11114/jets.v5i12.2713

URL: https://doi.org/10.11114/jets.v5i12.2713

\begin{abstract}
The purpose of this research is to examine the effects of secondary school administrators' servant leadership behavior on teachers' organizational commitment. This research was designed based on the relational screening model. The population of the study consists of 753 secondary school teachers. 438 teachers from the total population participated in the study. In the analysis of the data, descriptive statistics such as percent, frequency, arithmetic mean, standard deviation and other statistical techniques such as ANOVA, t-test, and regression analysis were used. According to the research findings, school administrators have some modest and responsible managerial, empowerment and forgiveness behaviors. Teachers' level of adaptation of organizational commitment is moderate and is found to be at a high level in the sub-dimension of identification and internalization. Teachers' views on organizational commitment do not differ according to gender, marital status or seniority. Teachers' views of school administrators on servant leadership behaviors do not differ according to their marital status but differ according to their gender and seniority.
\end{abstract}

Keywords: servant leadership, organizational commitment, school administrator, teacher

\section{Introduction}

In the developing and changing world, the increase in the importance given to human relations and human values brings to the forefront the concept of "human oriented management." In recent years, leadership approaches focusing on the needs of employees, developing more creative and effective business potential, empowering employees, and attaching importance to ethical values beyond short-term profitability have begun to gain importance (Akdöl, 2015: 3). It is expected that school administrators will play leadership roles instead of administrative roles. Such a leader is not someone who uses his power to dominate others; (Northouse; 2013: 233).

Nowadays there is a need for leaders who will take on more responsibility to manage a school effectively. Beyond individual and selfish demands, the concept of servant leadership that guides itself for the development of organizational members and for meeting organizational needs will help the educational institutions to work effectively and efficiently (Akyüz and Eren, 2013: 198).

\subsection{Servant Leadership}

Servant leadership is a new generation of leadership that was initiated by Robert Greenleaf in the 1970s. Greenleaf first used the term "Servant as a Leader" in his 1970 issue entitled "Servant Leader." Greenleaf developed the concept of servant leadership from the main figure Leo of Hermann Hesse's novel "Journey to the East." According to Greenleaf, putting the "servicing" mentality in the foreground is the most important direction of effective leadership (Spears, 1996: 33).

This has inspired scientists to develop basic ideas about servant leadership (Northouse, 2013: 220). These basic ideas: determining the needs of employees and trying to meet them, trying you keep their interests as a top priority are the means of service and are made consciously by the leader.

According to Page and Wong, someone who is a servant leader is a person who works for the benefit of the organization and contributes to and serves the development and interests of followers to achieve organizational goals (2000: 2); Drucker describes servant leader as a person who takes risks, serves, promotes occupations, supports rather than directs,

*This article is produced from Fatma Türkmen's master's thesis 
and listens to others (2000: 309). Servant leadership is a concept of leadership that sees the interests of employees over the leader's personal interests (Laub, 1999: 9); a new leadership model that prioritizes serving its followers (Spears, 1996: 33), is a form of special leadership that makes organizations more workable (Blanchard et al., 2007: 293).

Since Greenleaf (1972) did not make a clear definition of servant leadership and did not set out a conceptual framework, subsequent scientists tried to explain his ideas and show how the ideal servant leader should behave (Akdöl, 2015: 24). The first studies in this area focused on the definition and distinguishing features of servant leadership. Spears defines ten characteristics of servant leadership: listening, empathy, healing, awareness, persuasion, conceptualization, foresight, stewardship, commitment to the growth of people and building community, all based on Greenleaf's ideas (2005: 3-4). These ten features are the among first models or conceptualized versions of the concept of servant leadership (Northouse, 2013: 221-222). Six key concepts of servant leadership are to value people, to develop people, to build community, to display authenticity, to provide leadership and to share leadership (Laub (1999: 9).) In another conceptual study, servant leadership was conceptualized in a different model as character, relationship, leadership task, leadership process, leadership role model (Page and Wong, 2000: 4). Patterson's (2003: 2) servant leadership model consists of seven virtuous structures: (a) agapao love, (b) humility, (c) altruism, (d) vision, (e) trust, (f) empowerment, and (g) service. Dennis and Bocernea (2005: 610-611) developed an assessment and evaluation instrument based on Patterson's servant leadership model, in which the servant leadership was described by a five-factor structure as such: empowerment, humility, love, trust and vision. According to Barbuto and Wheeler (2006: 318-319), servant leadership consists of five dimensions: altruistic calling, emotional healing, persuasive mapping, wisdom, and organizational stewardship. Van Dierendonck and Nuijten (2011: 251-252) define servant leadership in eight dimensions: standing back, forgiveness, courage, empowerment, accountability, authenticity, humility, and stewardship.

Servant leadership is a concept based on the philosophy of "focusing on human needs as a top priority," and "service orientation" that go beyond the leadership understanding of previous standard leadership skills (Balay et al., 2014: 230). Servant leadership is a leadership style that aims to build common values for all employees with the philosophy of "servant leadership dedicated to the development of mankind," advocating the principle of sharing rights and powers for all employees as a strategic prescription in the structuring of organizations (Dinçer ve Bitirim, 2007: 68).

Servant leaders are unselfish idividuals who think about others' needs before their own. Educational institutions can be regarded as the proper places for sevant leaders who are self-conscious, foreseeing to stay away from selfishness, encourage an atmosphere of teamwork and cooperation, and whose main function is to help people to find better opportunities (Akyüz and Eren, 2013: 198). According to Crippen (2005), school leaders, are responsible for the development of democratic relations between parents, teachers and administrators, implementation of citizenship values, and the protection of them along with students' learning and teacher teaching activities (Cerit, 2005: 5). School leaders who demonstrate servile leadership behaviors will also find the power to serve their students better and to improve the school environment so that they will make a great effort to increase student achievement and achieve the desired educational goals.

\subsection{Organizational Commitment}

Organizational commitment, seen as one of the attitudes of business people, is one of the concepts that have been investigated deeply as a concept of modern management since the 1970s. According to Wyhte (1956), organizational commitment is a normal need, and one tries to meet this need in every aspect of social life (Acta Carapostal, 2014: 71).

Organizational commitment, according to Çöl (2004: 233), is defined as the individual's attitudes that give priority to organizational interests above his own interests. According to Çekmecelioğlu (2006: 155), it is defined as the desire of employees to stay in the organization, the commitment to organizational goals and values. According to Akıncı Vural and Coşkun (2007: 143), it is defined as the willingness to continue to be an active member of the organization and tie the level of identity together with a particular organization. According to Bakan (2011: 7), it is defined as the identification of the employee with the organization and the relative level of the strength of the identity unification. According to Saglam Ar1 (2003: 22) it is defined as the level of identification and integration that an individual feels towards a particular organization. According to Allen and Meyer (1990: 1), it is defined as the psychological state of the individual towards an organization. According to Steers (1977) it is defined as identity strength and the degree of participation e in an organization (Randall, 1987: 461).

According to Porter and Smith (1976), organizational commitment can be characterized by at least three factors: 1Belief in organization and the acceptance of goals. 2- Being willing to make efforts on behalf of the organization. 3Preserving organizational membership with a definite desire (Akt and Angel and Perry, 1981: 2, Mishra, 2005: 89). In another definition, organizational commitment is defined as three concepts which are recognition, long-term membership and extra role behaviors. Recognition means that the individual adopts the goals and objectives of the organization, long-term membership, loyalty toward organization; extra role behavior refers to high performance (Scholl, 2008: 1). 
Organizational commitment is a factor that increases organizational effectiveness and productivity. Today's intensely competitive environment requires human resources with a high level of commitment, which can combine physical, emotional and intellectual energies to achieve desired organizational outcomes (Akıncı Vural and Coşkun, 2007: 141-142). It is important for employees to adopt organizational goals and values for organizational success and to provide organizations with human resources (Bakan, 2011: 40-41). In order to provide modern and effective equipment in organizations, it is not enough to do well in the required tasks in terms of quality and quantity, but it is required that the motivation of personnel for production should be enhanced (Balc1, 1985: 2). Organizations formed by low levels of organizational commitment can not be successful (Kaya and Selçuk, 2007: 176).

Employees with a high level of commitment have a strong belief in the goals and values of the organization, demonstrate a high-level performance in order to achieve their goals, and are committed to continue to work in their organizations (Balay, 2000a: 3). When the connections that employees establish with the organization are low or weak, the level of productivity decreases and the quality of the product and service is adversely affected. The job and organizational satisfaction of employees is as important as producing services, (Serin, 2011: 68), which enables organizations to work efficiently and helps them achieve their goals. It is thought that organizational commitment is an important determinant diagnosising employees' behavior related to work. Organizational commitment is a concept closely related to organizational success.

A good teaching environment is largely based on the teachers' organizational knowledge and commitment. This can only be achieved by teachers with high organizational commitment. Employees with a high level of commitment to their organizations have the opportunity to advance in their career even further by doing their best through increasing their performance (Işı1k, 2014: 67). Organizational commitment is also an important variable for organizational effectiveness. Teachers who are attached to their institutions will have more responsibility, will do their best in their jobs, and will act more consciously while fulfilling their roles. This will help reduce organizational costs (Balc1, 2003: 16).

The teachers' attachment to their schools is seen as one of the most important indicators of an effective school (Balc1, 1993: 3). The student and teaching commitment can be regarded as one of the basic characteristics of an effective school at the same time. It is also known that administrators who share the decision-making process with stakeholders in school and focus on educational reforms contribute to establishing a higher level of organizational loyalty from teachers (Eskiköy Aydoğan, 2010: 83-84).

\subsection{Servant Leadership and Organizational Commitment}

The concept of management has an important place in the education system. The manager's skill and ability to manage greatly influences the success of the training system. However, professional knowledge and skills are not sufficient for a successful management alone. The attitude and behavior of the manager and the commitment of the teachers to their schools, their willingness to use their knowledge and skills for their organizations is also necessary for successful management. By exhibiting servant leadership behaviors, managers can achieve desired success in organization management (Mazarei et al., 2013: 316) because many of the servant leadership behaviors are consistent with the behaviors recommended to leaders for effective organizational management and are considered to increase the organizational commitment of employees. The school administrator can increase the level of commitment of teachers to the school with effective servant leadership behaviors. Increased commitment to the school also increases effectiveness of the teacher by increasing the performance. The quality of education in effective schools varies depending on teacher performance (Cerit, 2010: 306). Servant leaders who prioritize the needs of their followers, support team work in organizations, increase the self-confidence of the employees, influence the organizational and loyalty of the employees positively in this way (Mazarei et al., 2013: 316). In sum, school managers 'leadership behaviors and teachers' organizational commitment can be regarded as two factors that are effective in achieving the goals of educational organizations (Serin, 2011: 2).

\subsection{Purpose of the Research}

The purpose of this research is to examine the effect of the Servant Leadership behaviours of secondary school administrators on the organizational commitment of teachers. For this purpose, the answers to the following questions were sought:

1 - What are the opinions of teachers and school administrators regarding the servant leadership behaviors?

2 - At what level is the organizational commitment of the teachers?

3 - Do teachers' views on school managers' servant leadership behaviors and teachers' organizational commitment levels show significant differences according to gender, marital status and seniority?

4 - Are the school's leadership behaviors a predictor of teachers' organizational commitment? 


\section{Method}

This research was designed based on the relational screening model within the general screening models. The general screening models are the models in which a sample that is to be taken from all or a part of the population for the research is conducted to the total population in order to make a general judgment about a population consisting of a large number of elements. The relational screening model is an approach aimed at determining the presence or degree of mutual exchange between two or more variables (Karasar, 2014: 77-81).

The Population and Sample of the Research

The study's population consists of seven out of fifty-three (June 2015) secondary school teachers from forty-two secondary schools located in the districts of Sinop province in the academic year 2014-2015. All schools in the area were reached out to. The scale forms were completed by 443 teachers out of 753 teachers in the research population and since eleven forms were not filled properly in accordance with the directives, they were not evaluated or statistically analyzed. Gender, marital status and seniority distributions of the teachers participating in the research are given in Table 1.

Table 1. Gender, marital status and seniority distributions of the teachers participating in the research

\begin{tabular}{|c|c|c|c|}
\hline Variable & Level & $\mathrm{N}$ & $\%$ \\
\hline \multirow{3}{*}{ Gender } & Female & 215 & 49 \\
\hline & Male & 223 & 51 \\
\hline & Total & 438 & 100 \\
\hline \multirow{3}{*}{ Marital Status } & Married & 292 & 67 \\
\hline & Single & 146 & 33 \\
\hline & Toplam & 438 & 100 \\
\hline \multirow{5}{*}{ Seniority } & $1-5$ year & 166 & 38 \\
\hline & $6-10$ year & 102 & 23 \\
\hline & $11-15$ year & 84 & 19 \\
\hline & 16 year and above & 86 & 20 \\
\hline & Total & 438 & 100 \\
\hline
\end{tabular}

When the gender distributions of the teachers participating in the research are examined in Table 1, both males and females participated in working at similar ratios and most of them are married with 1-5 years of seniority. Those remaining have 6-10 years and 16 years and over and 11-15 years of seniority respectively.

Data Collection Tools

In this study, the views of teachers were taken as data. Two scales were used simultaneously. One of them is the Servant Leadership Scale developed by Dierendonck and Nuijten (2011) and the other is the Organizational Commitment Scale developed by Balay (2000b).

The adaptation of the Servant Leadership Scale to Turkish was done by Duyan (2012). Explanatory factor analysis on the scale revealed $64 \%$ of the total variance, it was found to be 26 items in scale and showed a 4 -factor structure. The Cronbach Alpha values of modest and responsible managerial levels was found to be .95 , empowerment is found to be .96 , accountability is found to be .87 , and forgiveness is found to be.83. The scale consists of 6 Likert types: I absolutely disagree (1), disagree (2), partially disagree (3), partially agree (4), agree (5), strongly agree (6). Responsible management consists of 15 items, standing back consists of 4 items, courage consists of 4 items and humility consists of items. As a result, it can be said that the four factors that can be seen in educational organizations can clearly explain level servant leadership.

The Organizational Commitment Scale consists of 27 items in three dimensions (conformity -identification-internalization). The total amount explained in the scale is 56.7\%. Cronbach Alpha values were found to be .79 in the dimension of conformity, .89 in the dimension of identification and .93 in the dimension of internalization. The scale consists of 5 Likert types: I do not agree (1), somewhat agree (2), moderately agree (3), strongly agree (4), fully agree" (5). It can be said that the Organizational Commitment Scale is a valid and reliable measurement tool with three factors.

Analysis of Data

In the analysis of the data, SPSS 21 was used. The collected data are classified according to the subproblems and these are loaded in the SPSS program. In the analysis of the data obtained in the research, descriptive statistical techniques such as percent, frequency, arithmetic mean, standard deviation, as well as statistical techniques such as one-way ANOVA, t-test, and regression analysis were used. 


\section{Results}

According to the sub-problems of the research, the leadership behaviors of the school administrators and the organizational commitment levels of the teachers were calculated. They then are investigated whether they differed according to their gender, marital status and seniority. Whether or not the servant leadership behaviors that school administrators have are a predictor of the level of organizational commitment teachers have was also examined.

1) Teachers' Organizational Commitment Levels with the Servant Leadership Behaviors of School Administrators

According to teachers' opinions, findings regarding the leadership behaviors of school managers and the level of organizational commitment that teachers have are given in Table 2.

Table 2. Servant Leadership Behavior and Teacher's Organizational Commitment Levels of School Administrators

\begin{tabular}{llccc}
\hline Variable & Sub-dimensions & $\mathrm{N}$ & $\mathrm{X}$ & $\mathrm{Sd}$ \\
\hline \multirow{3}{*}{ Servant Leadership } & 1) Modest and Responsible Management & 438 & 3.84 & 1.02 \\
& 2) Reinforcement & 438 & 3.38 & 1.24 \\
& 3) Accountability & 438 & 2.68 & 0.91 \\
& 4) Forgiveness & 438 & 3.43 & 0.69 \\
& & & & \\
Organizational Commitment & 1)Conformity & 438 & 2.32 & 0.66 \\
& 2)Identification & 438 & 3.05 & 0.91 \\
& 3)Internalization & 438 & 3.45 & 0.87 \\
\hline
\end{tabular}

According to the opinions of the teachers in Table 2, it is understood that teachers partially agree in the modest and responsible management, forgiveness, and empowerment sub-dimensions of servant leadership behaviors that school administrators have and that teachers moslty prefer "partially disagree" in the accountability sub-dimension. When the level of organizational commitment that teachers have is examined, it is understood that they fully agree with the identification and internalization dimensions of organizational commitment, and it is understood that the level of conformity is moderate in the organizational commitment sub-dimension.

1) Examination of Teacher Opinions of School Administrators on Servant Leadership Behaviors and Teachers' Organizational Commitment Levels

a) Gender

The levels of teachers' leadership attitudes and the organizational commitment of teachers according to gender is presented in Table 3.

Table 3. Comparison of School Administrators 'Servant Leadership Behaviors and Teachers' Organizational Commitment Levels According to Gender

\begin{tabular}{llllllcc}
\hline Değişken & Türü & $\mathrm{N}$ & $\mathrm{X}$ & $\mathrm{sd}$ & $\mathrm{df}$ & $\mathrm{t}$ & $\mathrm{p}$ \\
\hline Servant & Female & 215 & 3.97 & .56 & 436 & 2.86 & $.000 *$ \\
Leadership & Male & 223 & 3.78 & .78 & & \multirow{2}{*}{1.34} & .940 \\
Organizational & Female & 215 & 2.90 & .50 & 436 & & \\
Commitment & Male & 223 & 2.97 & .51 & & & \\
\hline
\end{tabular}

In Table 3, It has been found that there is a significant difference between the male and female teachers in favor of women teachers according to the gender variable in terms of the school administrators' servant leadership behaviors $(\mathrm{t}=2.86 ; \mathrm{p}<.05)$, but there was no significant difference in the views of organizational commitment in terms of the gender variable $(\mathrm{t}=1.34 ; \mathrm{p}>.05)$. Female teachers see school administrators as more servant leaders then male teachers.

b) Marital status

Table 4 presents the comparison levels of teachers' organizational commitment with the servant leadership behaviors of school administrators according to the marital status variable

Table 4. Comparison of School Administrators 'Servant Leadership Behaviors and Teachers' Organizational Commitment Levels According to Marital Status

\begin{tabular}{llllllll}
\hline Variable Type & $\begin{array}{l}\text { Variable } \\
\text { Type }\end{array}$ & $\mathrm{N}$ & $x$ & $\mathrm{sd}$ & $\mathrm{df}$ & $\mathrm{t}$ & $\mathrm{P}$ \\
\hline Servant & Married & 292 & 3.81 & .72 & 436 & 2.52 & .100 \\
Leadership & Single & 146 & 3.99 & .60 & & & \\
Behaviors & & & & & & & .580 \\
Organizational & Married & 292 & 2.95 & .49 & 436 & 0.77 & \\
Commitment & Single & 146 & 2.91 & .52 & & & \\
\hline
\end{tabular}

In Table 4, it was seen that there was no significant difference in the opinions of the teachers about the organizational 
commitment of the teachers and the supervisory leadership behaviors of the teachers according to the marital status variable $(t=2.52, p>.05 ; t=0.77 ; p>.05)$. Married and single teachers have similar views.

c) Seniority

Table 5. Compares the level of organizational commitment of the teachers with the senior leadership behaviors of school administrators and seniority variable

\begin{tabular}{lllllll}
\hline & Source of Variance & Sum of Squares & df & Mean Square & F-Ratio & $\mathrm{p}$ \\
\hline Servant Leadership & İntergroups & 11,1462 & 3 & 3.71 & & \\
& İntra Groups & 197,529 & 434 & 0.45 & & .16 \\
& Total & 208,675 & & & & \\
Organizational & İntergroups & 1,724 & 3 & 0.57 & \multirow{2}{*}{2.24} & .082 \\
Commitment Levels & İntra Groups & 111,040 & 434 & 0.25 & & \\
& Total & 112,764 & & & & \\
\hline
\end{tabular}

In Table 5, teachers' views of school administrators on servant leadership behaviors differ significantly from seniority (F $=8.16 ; \mathrm{p}<.05)$. Teachers' views on seniority at the level of organizational commitment do not show any significant difference $((F=2.24, p>.05$. Based on these results, multiple comparisons were made to understand which groups the difference is. The Dunnett T3 test was performed since the variance among groups was homogeneous $(\mathrm{F}=: 8.163 ; \mathrm{p}$ <.001). Table 6 presents the results of multiple comparisons according to the seniority variable of teacher opinions on school administrator's servant leadership behaviors.

Table 6. Multiple Comparison Results According to Seniority Variables of School Administrators' Servant Leadership Behaviors

\begin{tabular}{|c|c|c|c|c|c|}
\hline & School Type (I) & School Type (J) & Average Difference (I-J) & $\mathrm{Se}$ & $\mathrm{p}$ \\
\hline $\begin{array}{l}\text { Dunnett } \\
\text { T3 }\end{array}$ & $\begin{array}{l}11-15 \\
16 \text { and above }\end{array}$ & $\begin{array}{l}6-10 \text { year } \\
11-15 \text { year } \\
16 \text { year and above } \\
1-5 \text { year } \\
11-15 \text { year } \\
16 \text { year and above } \\
1-5 \text { year } \\
11-15 \text { year } \\
16 \text { year and above } \\
1-5 \text { year } \\
11-15 \text { year } \\
16 \text { year and above }\end{array}$ & $\begin{array}{l}.21237 \\
.35484 \\
.37108^{*} \\
-.21237 \\
.14247 \\
.15871 \\
-.35484^{*} \\
-.14247 \\
.01623 \\
-.37108^{*} \\
-.15871 \\
-.01623 \\
\end{array}$ & $\begin{array}{l}.07726 \\
.07949 \\
.10861 \\
.07726 \\
.09049 \\
.11690 \\
.07949 \\
.09049 \\
.11839 \\
.10861 \\
.11690 \\
.11839\end{array}$ & $\begin{array}{l}.038^{*} \\
.000^{*} \\
.005^{*} \\
.038^{*} \\
.052 \\
.684 \\
.000^{*} \\
.523 \\
1.00 \\
.005^{*} \\
.684 \\
1.00\end{array}$ \\
\hline
\end{tabular}

In Table 6, when the results of multiple comparisons are compared according to the seniority variable of teachers' views of school administrators on servant leadership behaviors, It is seen that there is a significant difference between those who have $1-5$ years seniority and those who have ages $6-10$ years, $11-15$ years and 16 years seniority $(p=.038<.05 ; p=, 000<.05$; $\mathrm{p}=.005<.05$ ). It can be said that young teachers regard school administrators as more servant leaders than other teachers.

2) Whether School Administrators 'Servant Leadership Behaviors are a Predictor of Teachers' Organizational Commitment

Findings in Table 7 show whether the teachers 'leadership behaviors are predictive of teachers' organizational commitment level.

Table 7. Regression Analysis Results between School Administrators 'Servant Leadership Behaviors and Teachers' Organizational Commitment

\begin{tabular}{llllllll}
\hline Variable & $\mathrm{B}$ & $\begin{array}{l}\text { Standart } \\
\text { Deviation B }\end{array}$ & $\beta$ & $\mathrm{t}$ & $\mathrm{p}$ & $\begin{array}{l}\text { Binary } \\
\mathrm{r}\end{array}$ & $\begin{array}{l}\text { Partial } \\
\mathrm{R}\end{array}$ \\
\hline $\begin{array}{l}\text { Constant } \\
\begin{array}{l}\text { Servant } \\
\text { Behaviors }\end{array}\end{array} \quad$ Leadership & 47.973 & 3.09 & & 15.52 & .00 & & \\
\hline $\mathrm{R}=.43 ; \quad \mathrm{R}^{2}=.19 ; \quad \mathrm{F}=103.423 ; \mathrm{p}=.000$ & 0.291 & .02 & 0.43 & 10.17 & .00 & .43 & .19 \\
\hline
\end{tabular}

In Table 7, when the findings of whether school-based leadership behaviors are a predictor of teachers' organizational commitment are examined; $(\mathrm{R}=.43)$, it was found that here was a positive relationship between the level of organizational commitment of teachers and the servant leadership behaviors of school administrators and that the servant leadership explains $19 \%$ of the effect on organizational commitment $\left(\mathrm{R}^{2}=192\right)$. The model is thought to be significant $(\mathrm{F}=103.423$; sig.=.000). The model for predicting teachers' organizational commitment of servant leadership behaviors can be established as follows: $(\mathrm{t}=15.52$; sig.=.000): Organizational Dependency $=47.973+0.291 *$ Servant leadership 


\section{Discussion}

When findings are evaluated together in this study, which deals with the relationship between the servant leadership behaviors of school administrators and the organizational commitment levels of teachers, teachers moslty prefer "partially agree" in the sub-dimensions of school administrators' servant leadership behaviors as moderating and responsive management, forgiveness, and empowerment teachers moslty prefer "partially disagree" in the accountability sub-dimension, when the level of organizational commitment that teachers have is examined. It is understood that they fully agree with the identification and internalization dimensions of organizational commitment, and it is understood that the level of conformity is moderate in the organizational commitment sub-dimension.

According to teachers, school administrators partially have the dimensions of modesty and responsible management, strengthening and forgiveness. Findings are consistent with the findings of Cerit (2007) and Cerit (2008). In this study, a negative relationship between empowerment, emotional exhaustion, depersonalization and personal failure was found. Findings can also be interpreted as the fact that the managers do not have such competence, or the teachers do not expect empowering and improving behaviors from school administrators. The findings are also consistent with the findings of Şişman (2012) and Celep (2004). In these studies, it has been pointed out that the leadership behaviors exhibited by school administrators are inadequate in terms of the support and development of teachers. Gül and Turkmen (2016: 5524) stated that school administrators partially fulfill the attitudes of strengthening their servant leadership behavior. At the center of empowerment, there is the fact that the servant leader has the belief in the inner value of every employee (Dierendonck and Nuijten, 2011). Teachers can be empowered to increase their loyalty. Strengthened employees can take on more responsibilities, improve their skills and make their own decisions. Findings related to the sub-dimension of forgiveness show consistency with the results of Gul and Türkmen (2016). As the servant leader, school administrators should show forgiveness and create appropriate environments. Decreasing strictness in management and clarity within the organization helps to reveal the potential of employees (Duyan, 2012). Accountability is a concept related to controlling the performance of employees and being responsible for their work, and is one of the important behaviors that managers should possess. It is an effective tool for the servant leader to show confidence in his employees. Findings of Gül and Türkmen (2016: 5524) are not consistent with the results of the research. In their study, it was found that school administrators are sufficient in terms of accountability of servant leadership behaviors. Accountability is a legal obligation beyond being a subdimension of servant leadership. The failure of an administrator to account for work brings with it a number of legal issues.

According to research findings, teachers assessed themselves moderately in the conformity sub-dimension of organizational commitment. The findings of the study show that compliance loyalty is moderate. The findings are consistent with the findings of Imamoğlu (2011). In Atmaca's (2014) study, teacher perceptions were found to be low in the dimension of harmony between the types of power used by school administrators and organizational commitment of teachers. Awards distributed within the organization may increase organizational commitment (Celep, 2014). The desire to receive a prize, the limited availability of alternative employment opportunities in the teaching profession, the lack of managerial progress and the desire to increase lead to a higher compliance commitment (Balay, 2000b). According to Imamoğlu (2011), it is not very desirable that the compatibility of education organizations is high.

Teachers' levels of organizational commitment are at the level of "fully agree" in the identification dimensions of identity and internalization. Teachers have a high degree of identification and internalization. Identification depends on the desire to be a member of a group and to maintain it and to establish social relations (Bakan, 2011). The findings of this study are inconsistent with the findings of Imamoğlu (2011). In this study, teachers' identification was found to be moderate level. It has been found that the teachers working in private high schools have higher identification dependence than the teachers in the official high schools (Balay, 2000b). Teachers' identification of identity allows them to develop their educational abilities and empowers them to be part of the community. Teacher competence in the subjects such as teacher's personal characteristics, professional competence, socialization, parent teacher communication affects the identification of identity (Balc1, 1993).

Internalization commitment is the most desirable form of commitment (Minister, 2011). Teachers working in private high schools were found to have a higher internalization commitment than teachers in official high schools (Balay, 2000b). The findings of this research show consistency with the findings of İmamoğlu (2011) and Atmaca (2014).

Teachers ' views on the school administrators' leadership behaviors differ in favor of women by gender. Findings showed consistency with Ekinci (2015) and Dogan (2015) researches, but did not show consistency with the findings of Cerit (2005) and Balay et al. (2014). Teacher views do not differ according to the marital status variable. Findings are consistent with Dogan's (2015) research. Teacher opinions differ according to their seniority. Findings are consistent with the findings of Balay et al. (2014) and Doğan (2015).

Teachers' views on organizational commitment do not differ according to gender, marital status and seniority. While findings 
showed consistency with Selvitopu and Şahin's (2013) research, it does not show consistency with the findings of Ertürk (2011). In Balay's study (2000b), there was a significant difference in favor of male teachers in the subscale of identity and internalization, while no significant difference was observed in gender in the conformity subdimension. According to the seniority variable, the findings are inconsistent with the findings of Cömert (2014) and Selvitopu and Şahin (2013).

It can be said that the servant leadership behaviors that school administrators have can be regarded as the predictor of the organizational commitment of teachers (Doğan, 2015, Cerit, 2010, Mazarei et al., 2013). Servant leadership behaviors have a significant effect on employee commitment (Sokall, 2014, Olesia et al., 2013, Chinomona et al., 2013, Jacobs, 2006, Ambali et al., 2011, Bocarnea and West, 2008, Goh and Low, 2013). Drury (2004) found a significant inverse relationship between organizational commitment and servant leadership, as opposed to what is stated in the literature.

\section{References}

Akıncı, V. Z. B., \& Coşkun, G. (2007). Organizational Culture: Communication, Leadership, Motivation, Commitment, Performance Evaluation. Ankara: Nobel Publication Distribution.

Akyüz, B., \& Eren, M. Ş. (2013). A Theoretıcal Study on the Effects of Servant Leadershıp Behaviors on Education Employees. Journal of Entrepreneurship and Development, 8(2), 191-205.

Allen, N. J., \& Meyer, J. P. (1990). The Measurement and Antecedents of Affective, Continuance and Normative Commitment to The Organization. Journal of Occupational Psychology, 63, 1-18. https://doi.org/10.1111/j.2044-8325.1990.tb00506.x

Ambali, A. R., Suleiman, G. E., Bakar, A. N., Hashim, R., \& Tariq, Z. (2011). Servant Leadership's Values and Staff's Commitment: Policy Implementation Focus. American Journal of Scientific Research, 13, 18-40.

American Psychological Association. (1972). Ethical standards of psychologists. Washington, DC: American Akdöl, B. (2015). Servant Leadership. Istanbul: Derin Publications.

Angle, H. L., \& Perry, J. L. (1981). An Empirical Assessment of Organizational Commitment and Organizational Effectiveness. Administrative Science Quarterly, 26(1), 1-14. https://doi.org/10.2307/2392596

Atmaca, T. (2014). Relationship among the power types of school principals' and teachers' mobbing, organizational commitment and organizational cynicism perception. (Unpublished Master Thesis). Gazi University, Faculty of Education Institute, Ankara.

Bakan, İ. (2011). Organizational Commitment Based on Organizational Strategies Concept, Theory, Cause and Results. Gazi Bookstore, Ankara

Balay, R. (2000a). Organizational Commitment in Managers and Teachers. Ankara: Nobel Publication Distribution.

Balay, R. (2000b). The organizational commitment of administrators and teachers in private and public second art schools (Sample of Ankara province). (Unpublished Doctoral Thesis) Ankara University, Institute of Social Sciences, Ankara.

Balay, R., Kaya, A., \& Geçdoğan, Y. R. (2014). The Relationship between Servant Leadership Competences and Diversity Management Skills among Education Managers. Journal of Educational Sciences Research, 4(1), 229-249. https://doi.org/10.12973/jesr.2014.4os14a

Balc1, A. (1985). The organizational commitment of administrators and teachers in private and public second art schools (Sample of Ankara province) (Unpublished Doctoral Thesis). Ankara University, Institute of Educational Sciences, Ankara.

Balc1, A. (1993). Effective School: Theory, Practice and Research. Ankara: Yavuz Distribution.

Balc1, A. (2003). Research in Social Sciences: Methods, Techniques and Principles. Ankara: Pegem A Publishing.

Barbuto, J. E., \& Wheeler, D. W. (2006). Scale Development and Construct Clarification of Servant Leadership. Group \& Organization Management, 31(3), 300-326. https://doi.org/10.1177/1059601106287091

Blanchard, K. (2007). Leadership and Leadership and High Performance Institutions Blanchard Approach in Creation. (Trans.) Uçtum, F. Istanbul: Kaizen, Resital Publishing.

Bocarnea, M., \& West, G. R. B. (2008). Servant Leadership And Organizational Outcomes: Relationships In United States And Filipino Higher Educational Setting. Servant Leadership Research Roundtable, 1-20.

Çekmecelioğlu, H. (2006). Is Evaluation of the Effects of Satisfactory and Organizational Commitment Attitudes on Intention to Leave and Efficiency: A Research The Journal of Industrial Relations \& Human Resources, 8(2), 153-168. 
Celep, C. (2004). Transformational Leadership. Ankara: Anı Publishing.

Celep, C. (2014). Organizational Commitment in Educational Organizations. Ankara: Nobel Press.

Cerit, Y. (2005). The Effects of Servant Leadership Behaviors of Primary School Principals on Teachers' Burnout. Educational Administration: Theory and Practice, 6(2), 1-19.

Cerit, Y. (2007). Prımary School Prıncıpals' Levels Of Realızıng Servant Leadershıp Roles . H. U. Journal of Education, $33,88-98$.

Cerit, Y. (2008). The Effects of Servant Leadership Behaviors of Primary School Principals on Teachers' Burnout. Educational Administration: Theory and Practice, 55, 547-570.

Cerit, Y. (2010). The Effects of Servant Leadership on Teachers' Organizational Commitment İn Primary Schools İn Turkey. International Journal of Leadership In Education, 13(3), 301-317. https://doi.org/10.1080/13603124.2010.496933

Chınomona, R., Mashıloane, M., \& Pooe, D. (2013). The Influence of Servant Leadership On Employee Trust In A Leader And Commitment to the Organization. Mediterranean Journal of Social Sciences, 4(14), 405-414. https://doi.org/10.5901/mjss.2013.v4n14p405

Çöl, G. (2004). A study on the relationship between empowerment and organizational commitment (Unpublished Doctoral Thesis). Gebze Institute of Technology, Institute of Social Sciences, Gebze.

Cömert, M. (2014). Analysis of relation between teacher's organizational commitment level and principals's power sources (Unpublished Master Thesis). Kahramanmaras Sutcu Imam University, Institute of Social Sciences, Kahramanmaraş.

Dennis, R. S., \& Bocernea, M. (2005). Development of The Servant Leadership Assessment Instrument. Leadership \& Organization Development Journal, 26(8), 600-615. https://doi.org/10.1108/01437730510633692

Dierendonck, D. V., \& Nuijten, I. (2011). The Servant Leadership Survey: Development And Validation Of A Multimensionel Measure. J. Bus. Psychol., 26, 249-267. https://doi.org/10.1007/s10869-010-9194-1

Dinçer, M. K., \& Bitirim, S. (2007). Creatıng Value Wıth Inıtıatıves Of Servıce Leadershıp In Instıtutıonal Culture Studies. stanbul University Faculty of Communication Journal

Doğan, Ü. (2015). The relationship between the special education teachers and the organizational dedication level of the special education teachers and the perception level of servant leadership behaviour of headmasters. (Unpublished Master Thesis). Ondokuz Mayıs University, Institute of Educational Sciences, Samsun.

Drucker, P. F. (2000). Future Leader. Istanbul: Form Publishing.

Drury, S. L. (2004). Servant Leadership And Organizational Commitment: Empirical Findings and Workplace Implications. Servant Leadership Research Roundtable, Erişim: 4 Aralık 2015, http://www.Regent.Edu/Acad/Sls/Publications/Conference_Proceedings/Servant_Leadership_Roundtable/2004pdf/ Drury_Servant_LeadershIp.Pdf

Duyan, E. C. (2012). Servant Leadership: A Study on the Relationships between Employee Well-Being and Quality of Working Life. (Unpublished Doctoral Thesis). Uludağ University, Institute of Social Sciences, Bursa.

Ekinci, A. (2015). Development of the School Principals' Servant Leadership Behaviors Scale and Evaluation of Servant Leadership Behaviors According to Teachers' Views, Education and Science, 40(179), 341-360. https://doi.org/10.15390/EB.2015.2152

Ertürk, E. (2011). The relationship between perception of organizational justice and teachers? organizational commitment in primary and secondary schools. (Unpublished Master Thesis). Mehmet Akif Ersoy University, Institute of Social Sciences, Burdur.

Eskiköy, A. S. (2010). Organizational commitment levels of teachers in public schools. (Unpublished Master Thesis). Beykent University, Institute of Social Sciences, Istanbul.

Goh, S. K., \& Low, B. Z. J. (2013). The Influence of Servant Leadership Towards Organizational Commitment: The Mediating Role of Trust In Leaders. International Journal Of Business and Management, 9(1), 17-25. https://doi.org/10.5539/ijbm.v9n1p17

Greenleaf, R. K. (1970). The Servant As Leader. https://www.Leadershiparlington.Org Erişim: 10 Eylül 2015.

Gül, İ., \& Türkmen, F. (2016). Öğretmen Görüşlerine Göre Okul Yöneticilerinin Hizmetkar Liderlik Davranışlarının İncelenmesi. Journal of Human Science, 13(3), 5515-5529. https://doi.org/10.14687/jhs.v13i3.4290 
İmamoğlu, G. (2011). The relationshıp between primary school teachers? organizational commitment levels and organizational justice. (Unpublished Master Thesis). Gazi University, Institute of Educational Sciences, Ankara.

Işık, N. (2014). Servant leadership approaches and organizational commitment of employees to the effects of leadership. (Unpublished Master Thesis). Bahçeşehir University, Institute of Social Sciences Human Resources, Istanbul.

Jacobs, G. A. (2006). Servant Leadership and Follower Commitment. Servant Leadership Research Roundtable Regent University,Http://www.Regent.Edu/Acad/Sls/Publications/Conference_Proceedings/Servant_Leadership_Roundtab le/2006/Pdf/Gilbert.Pdf Erişim: 4 Aralık 2015

Karapostal, İ. O. (2014). The analysis of the relationship between the leadership styles of principals and the organizational commitment of high schools teachers (Sample of Aliağa, İzmir). (Unpublished Master Thesis). Okan University, Institute of Social Sciences, Izmir.

Karasar, N. (2014). Scientific Research Methods. Ankara: Nobel Academic Publishing.

Kaya, N., \& Selçuk S. (2007). How Does The Motıve Of Indıvıdual Achıvement Affect Organizatıonal Commıtment? Dogus University Journal, 8(2), 175-190.

Laub, J. (1999). Defining Servant Leadership: A Recommended Typology For Servant Leadership Studies. Sevant Leadership Research Roundtable, The School of Leadership Studies, Regent University.

Mazarei, E., Hoshyar, M., \& Nourbakhsh, P. (2013). The Relationships Between Servant Leadership Style and Organizational Commitment. Archives of Applied Science Research, 5(1), 312-317.

Mishra, G. P. (2005). Role of employee commitment in organizational effectiveness. Delhi Business Review, 6(2), 89-93.

Northouse, P. G. (2013). Leadership: Theory and Practice. (Çev) Şimşek, C. İstanbul: Sürat Yayınları.

Olesia, W. S., Namusonge, G. S., \& Iravo, M. A. (2013). Role of Servant Leadership On Organizational Commitment: An Exploratory Survey Of State Corporations İn Kenya. International Journal of Humanities And Social Science, 3(13), 85-95.

Page, D., \& Wong, P. T. P. (2000). A Conceptual Framework for Measuring Servant-Leadership. Trinity Western University, Langley, B. C.

Patterson, K. (2003). Servant Leadership: A Theoetical Model. Servant Leadership Research Roundtable, The School of Leadership Studies, Regent University, August.

Randall, D. M. (1987). Commitment And The Organization: The Organization Man Revisited. Academy of Management Review, 12(3), 460-471.

Sağlam Arı, G. (2003). Does The Trust For the Manager Increase Organizational Commitment, Gazi University Journal of Trade and Tourism Education, 2, 17-36.

Scholl, R. W. (2008). What İs Organizational Commitment? Charles T. Schmidt Labor Research Center, The University Of Rhode Island. 2015. http://www.Uri.Edu/Research/Lrc/Scholl/Webnotes/Commitment Erişim: 7 Aralık 2017

Selvitopu, A., \& Şahin, H. (2013). The Relationship Between Organizational Justice Perceptions and Organizational Commitment Levels of Secondary School Teachers. The Journal of Ahi Evran University Kirşehir Education Faculty, 14(2), 171-189.

Serin, M. K. (2011). The relationship between instructional leadership and organizational commitment in primary schools (A study in Konya) Unpublished Master's Thesis, Gazi University, Institute of Educational Sciences, Ankara

Şişman, M. (2012). Instructional Leadership. Ankara: Pegem Academy.

Spears, L. C. (1996). Reflections On Robert K. Greenleaf And Servant Leadership. Leadership Organization Development Journal, 17(7), 33-35. https://doi.org/10.1108/01437739610148367

Spears, L. C. (2005). The Understanding and Practice of Servant Leadership. Servant Leadership Research Roundtable, The School Of Leadership Studies, Regent University.

\section{Copyrights}

Copyright for this article is retained by the author(s), with first publication rights granted to the journal.

This is an open-access article distributed under the terms and conditions of the Creative Commons Attribution license which permits unrestricted use, distribution, and reproduction in any medium, provided the original work is properly cited. 